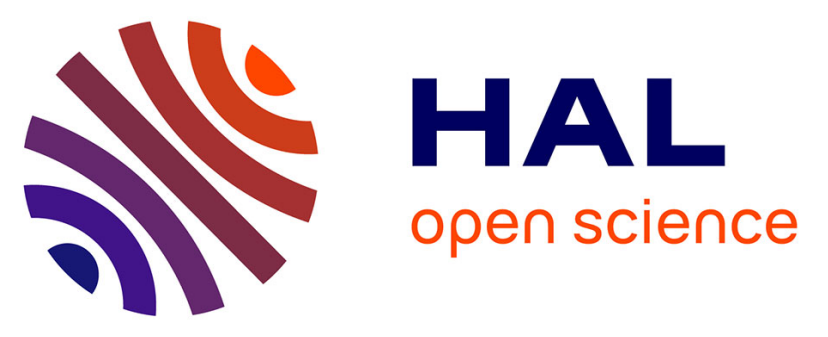

\title{
Ferrocifens labelled with an infrared rhenium tricarbonyl tag: synthesis, antiproliferative activity, quantification and nano IR mapping in cancer cells
}

Yong Wang, Franz Heinemann, Siden Top, Alexandre Dazzi, Clotilde Policar, Lucas Henry, François Lambert, Gérard Jaouen, Michèle Salmain, Anne Vessières

\section{To cite this version:}

Yong Wang, Franz Heinemann, Siden Top, Alexandre Dazzi, Clotilde Policar, et al.. Ferrocifens labelled with an infrared rhenium tricarbonyl tag: synthesis, antiproliferative activity, quantification and nano IR mapping in cancer cells. Dalton Transactions, 2018, 47 (29), pp.9824 - 9833. 10.1039/C8DT01582A . hal-01878514

\section{HAL Id: hal-01878514 https://hal.sorbonne-universite.fr/hal-01878514}

Submitted on 20 Dec 2018

HAL is a multi-disciplinary open access archive for the deposit and dissemination of scientific research documents, whether they are published or not. The documents may come from teaching and research institutions in France or abroad, or from public or private research centers.
L'archive ouverte pluridisciplinaire HAL, est destinée au dépôt et à la diffusion de documents scientifiques de niveau recherche, publiés ou non, émanant des établissements d'enseignement et de recherche français ou étrangers, des laboratoires publics ou privés. 


\section{Ferrocifens labelled with an infrared rhenium tricarbonyl tag: synthesis, antiproliferative activity, quantification and nano IR mapping in cancer cells. $\uparrow$}

Yong WANG, ${ }^{\mathrm{a}, \mathrm{b}}$ Franz HEINEMANN, ${ }^{\mathrm{a}}$ Siden TOP, ${ }^{\mathrm{a}}$ Alexandre DAZZI, ${ }^{\mathrm{c}}$ Clotilde POLICAR, ${ }^{\mathrm{d}}$ Lucas HENRY, , François LAMBERT, d Gérard JAOUEN, ${ }^{\mathrm{a}, \mathrm{b}}$ Michèle SALMAIN, ${ }^{\mathrm{a}^{*}}$ Anne VESSIERES $\mathrm{a}^{*}$

a) Sorbonne Université, CNRS, Institut Parisien de Chimie Moléculaire (IPCM), F-75005 Paris, France

b) PSL University, Chimie ParisTech, F-75005 Paris, France

c) Laboratoire de Chimie Physique, Université Paris-Sud, Bâtiment 350, F-91400 Orsay, France.

d) Laboratoire des BioMolécules, LBM, Département de chimie, École normale supérieure, PSL University, Sorbonne Université, CNRS, F-75005 Paris, France

† Electronic supplementary information (ESI) available. See DOI :

Keywords : bioorganometallic chemistry, iron, ferrocene, infrared spectroscopy, AFM-IR

* Corresponding authors 


\section{Table of contents}

Cyrhetrenyl $\left[\eta^{5}-\mathrm{C}_{5} \mathrm{H}_{4} \mathrm{Re}(\mathrm{CO})_{3}\right]$ tag allows localization of a cytotoxic iron/rhenium dimetallic complex in the nucleus of a single MDA-MB-231 breast cancer cell

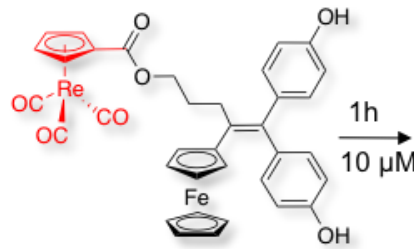

$\mathrm{IC}_{50}=2.5 \mu \mathrm{M}$ (MDA-MB-231 cells)

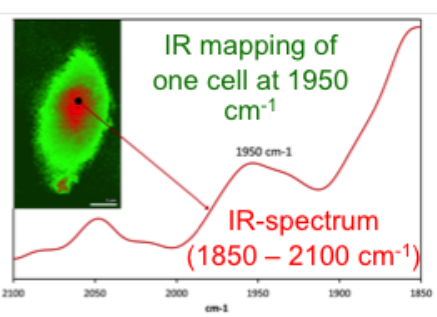




\begin{abstract}
Antiproliferative activities of several members of the ferrocifen family, both in vitro and in vivo, are well documented although their precise location in cancer cells has not yet been elucidated. However, two different infrared imaging techniques have been used to map the non-cytotoxic cyrhetrenyl analogue of ferrociphenol in a single cell. This observation prompted us to tag two ferrocifens with a cyrhetrenyl unit $\left[\mathrm{CpRe}(\mathrm{CO})_{3} ; \mathrm{Cp}=\right.$ $\eta^{5}$-cyclopentadienyl] by grafting it, via an ester bond, either to one of the phenols $(4,5)$ or to the hydroxypropyl chain (6). Complexes 4-6 retained a high cytotoxicity on breast cancer cells (MDA-MB-231) with $\mathrm{IC}_{50}$ values in the range $0.32-2.5 \mu \mathrm{M}$. Transmission IR spectroscopy was used to quantify the amount of cyrhetrenyl tag present in cells incubated with $\mathbf{5}$ or $\mathbf{6}$. The results show that after a 1-hour incubation of cells at $37^{\circ} \mathrm{C}$, complexes $\mathbf{5}$ and $\mathbf{6}$ are mainly present within cells while only a limited percentage, quantified by ICP-OES, remained in the incubation medium. AFM-IR spectroscopy, a technique coupling infrared irradiation with near-field AFM detection, was used to map the cyrhetrenyl unit in a single MDA-MB-231 cell, incubated at $37^{\circ} \mathrm{C}$ for 1 hour with 10 $\mu \mathrm{M}$ of 6 . The results show that signal distribution of the characteristic band of the $\operatorname{Re}(\mathrm{CO})_{3}$ entity at $1950 \mathrm{~cm}^{-1}$ matched those of amide and phosphate, thus indicating a location of the complex mainly in the cell nucleus.
\end{abstract}




\section{Introduction}

A member of the ferrocifen family, the diphenol complex 1a (Chart 1) has been described as one of the most effective molecules of the series showing strong antiproliferative effect both in vitro, on various cell lines ( IC $_{50}=0.64 \mu \mathrm{M}$ on MDA-MB231 cancer cells) and in vivo on growth inhibition of 9L glioma cells. ${ }^{1}$ More recently complex 2 , the hydroxypropyl ferrociphenol, has been synthesized. ${ }^{2}$ Its antiproliferative effect in vitro on MDA-MB-231 cancer cells is stronger than that of $1 \mathbf{a}\left(\mathrm{IC}_{50}=0.11 \mu \mathrm{M}\right)$. Thus it represents a new lead structure for highly active anti-cancer complexes.

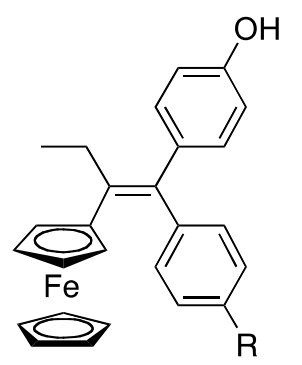

$1 \mathrm{a}: \mathrm{R}=\mathrm{OH}$

$1 b: R=H$

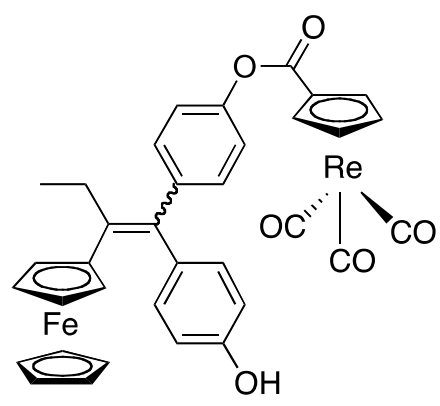

$(\mathrm{Z}+\mathrm{E})-\mathbf{4}$

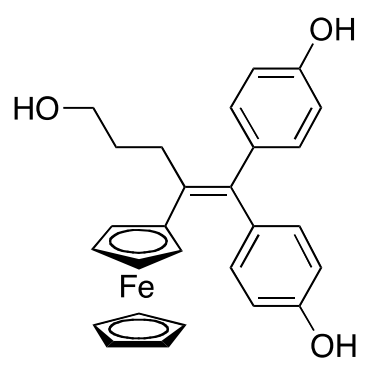

2

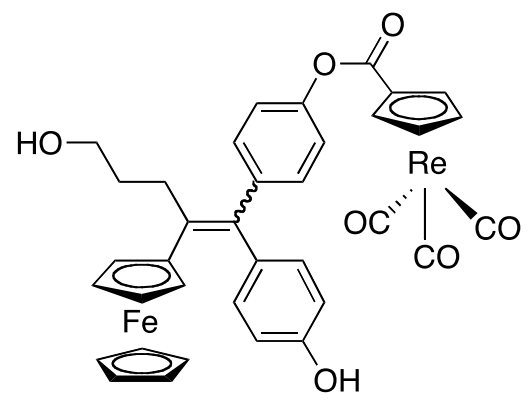

$(\mathrm{Z}+\mathrm{E})-5$

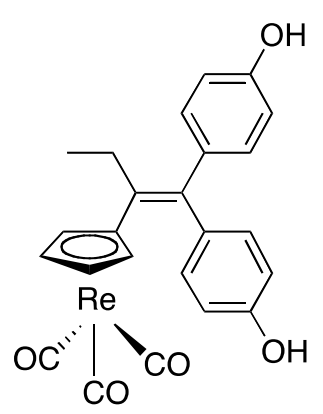

3

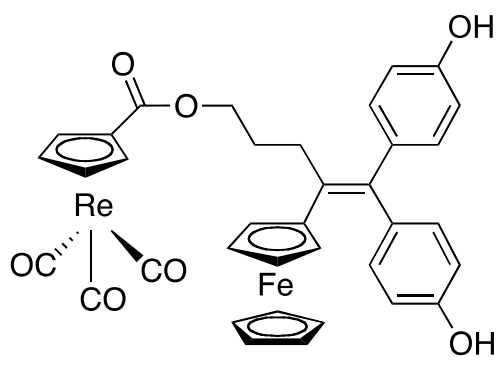

6

Chart 1 : Ferrociphenols (1a, 1b), cyrhetrenyl analogue (3), hydroxypropylferrociphenol (2) and ferrocenyl complexes bearing a cyrhetrenyl tag (4-6).

Although several studies have examined the biological activity of the ferrocifens, their mechanism of action is not fully understood. ${ }^{1}$ It has been associated with the unique redox properties of ferrocene, or indeed with the fact that ferrocifens are oxidized in cells into their highly electrophilic quinone methides (QMs). ${ }^{3,4}$ However, their precise targets and their location inside the cell has not yet been elucidated. In addition, there is recent evidence that the most effective members of the family probably act via different mechanisms of action. ${ }^{5}$

Various types of labels can be used to track exogenous molecules of interest in cells. ${ }^{6}$ The most developed ones are luminescent dyes that are grafted to the molecules 
under study. ${ }^{6}$ These probes can be purely organic molecules or metal-containing emitters, either coordination or organometallic complexes. ${ }^{6}$ However, ferrocene is well known for its strong ability to quench the luminescence of emitting species. ${ }^{7}$ This behaviour prevents access to fluorescent ferrocifens. ${ }^{8}$ On the other hand, two types of vibrational spectroscopies, namely mid-infrared and Raman have been recently introduced for mapping of metal-carbonyl $\mathrm{M}_{\mathrm{x}}(\mathrm{CO})_{\mathrm{y}}$ reporter groups within single cells. ${ }^{9-}$ 15 These species display intense and distinctive absorption bands, due to CO ligand stretching modes, between 1850 and $2100 \mathrm{~cm}^{-1}$, a zone in which proteins and other cellular materials do not absorb, thus creating a spectral window to the cell. ${ }^{16}$ We have contributed to the validation of this approach by mapping complex 3 (Chart 1), the cyrhetrenyl analogue of $\mathbf{1 a}$, in the nucleus of breast cancer cells using its characteristic IR signature.17, 18 Two different infrared techniques were employed. The first, SR-FTIRSM (Synchrotron radiation FTIR spectromicroscopy), is an optical technique using a mid-infrared source provided by a synchrotron. ${ }^{17}$ The second is AFM-IR, a cutting edge technique coupling infrared irradiation provided by a tunable laser with near-field AFM detection. ${ }^{18}$ In both cases, the complex was identified thanks to the two characteristic bands of the cyrhetrenyl unit located at $1920 \mathrm{~cm}^{-1}$ (E-band, antisymmetric stretching) and $2020 \mathrm{~cm}^{-1}$ (A1-band, symmetric stretching). Unfortunately, complex $\mathbf{3}$ is very much less cytotoxic than $\mathbf{1 a}$, thus its interest as a cytotoxic agent is limited. ${ }^{19}$ With the aim of gaining information on the distribution of ferrocifens in cancer cells, we decided to synthesize three new ferrocenyl complexes labelled with the $\mathrm{CpRe}(\mathrm{CO})_{3} \operatorname{tag}$ (4-6, Chart 1) but still possessing the Fc- double bond - phenol motif, which has been found to be essential for expression of their cytotoxicity in vitro. ${ }^{20}$ The synthesis and antiproliferative activity of two hybrid ferrocenyl/cyrhetrenyl aldimines has recently been published, ${ }^{21}$ but complexes 4-6 represent the first members of the ferrocifen family bearing these two organometallic units. Cytotoxicity studies and partition coefficient measurements were then performed on these new complexes, together with enzymatic oxidation studies by the horseradish peroxidase $/ \mathrm{H}_{2} \mathrm{O}_{2}$ system, quantification of the complexes in cell pellets by transmission FT-IR spectroscopy and of rhenium and iron in by ICP-OES. Eventually, localization of complex 6 in individual cancer cells was achieved by AFM-IR. 


\section{Experimental}

\section{General Remarks}

All reactions and manipulations were carried out under an argon atmosphere using standard Schlenk techniques. Anhydrous solvents were obtained by standard procedures. Complexes 1a, 2 and $\mathbf{7}$ were synthesized as described in ref ref ${ }^{22}$, ref ${ }^{2}$ and ref ${ }^{23}$, respectively. Other chemicals were purchased from various manufacturers and used as received. ${ }^{1} \mathrm{H}$ and ${ }^{13} \mathrm{C}$ NMR spectra were acquired on a Bruker $300 \mathrm{MHz}$ spectrometer. Chemical shifts ( $\delta$ ) are expressed as ppm referenced to the solvent residual signal. Splitting patterns are expressed as follows: $s$, singlet; $d$, doublet; $t$, triplet; q, quartet; p, pentet; m, multiplet; br, broad. Mass spectrometry was carried out at the "Service de Spectrometrie de Masse" of Chimie ParisTech (Paris). IR spectra were recorded on a Tensor 27 FT-IR spectrometer (Bruker). Inductively coupled plasma optical emission spectrometry (ICP-OES) analysis was performed on a JY2000 apparatus (Jobin-Yvon Horiba) at the Metis Laboratory of the University Pierre et Marie Curie. High resolution mass spectra (HR-MS) are reported in m/z. Elemental analysis was performed at the elemental analysis service of ICSN (Gif sur Yvette, France). Purity of the complexes was at least 95\% based on elemental analysis, NMR or analytical reverse phase HPLC with Nucleodur C18 column (4.6 x 150 mm) using MeOH/water (80/20) as eluent (Figures S1 - S3). Preparative RP-HPLC was performed on a C18-2 $10 \mu \mathrm{m}$, column (Interchrom) using $\mathrm{CH}_{3} \mathrm{CN} / \mathrm{H}_{2} \mathrm{O} 80: 20$ at $10 \mathrm{ml} / \mathrm{min}$ with detection set at $254 \mathrm{~nm}$.

\section{Synthesis of the complexes}

Tricarbonyl( $\eta^{5}$-chlorocarbonylcyclopentadienyl)rhenium(I) 8

Compound 7 (0.6 g, 1,6 mmol) was treated with oxalyl chloride ( $5.5 \mathrm{ml}, 65 \mathrm{mmol}$ ) in DCM $(70 \mathrm{ml})$ and heated to reflux. After $70 \mathrm{~min}$, volatiles were evaporated to afford 8 , which was used without further purification.

\section{2-Ferrocenyl-1-(4-hydroxyphenyl)-1-(( n-5-phenyloxycarbonylcyclopentadienyl)-} tricarbonyl-rhenium(I))-but-1-ene $(\mathbf{Z}+\boldsymbol{E})-\mathbf{4}$

Compound 1 (0.81 g, $1.6 \mathrm{mmol}$ ), DIPEA (1.1 mL, $6.3 \mathrm{mmol}, 4 \mathrm{eq}$ ) and DMAP (0.3 mmol, $0.2 \mathrm{eq})$ were dissolved in DCM. Acyl chloride 8 (0.6 g, $1.6 \mathrm{mmol})$ in DCM (50 mL) was added dropwise. The mixture was stirred for 4 days then washed twice with $0.5 \mathrm{M} \mathrm{HCl}$ $(100 \mathrm{~mL})$ and once with saturated sodium chloride solution. The product was first purified by column chromatography on silica gel (petroleum ether/ethyl acetate 10:1 ; 
$\mathrm{R}_{\mathrm{f}}=0.2$ ). Then the crude product was further purified by preparative RP-HPLC to give $260 \mathrm{mg}$ (yield: $20 \%$ ) of 4 as a mixture of E- and Z-isomers (the ratio of E/Z isomers was around 50:50 according to ${ }^{1} \mathrm{H} \mathrm{NMR}$ ).

${ }^{1} \mathrm{H}$ NMR (300 MHz, Acetone-d 6$) \delta 8.31(\mathrm{~s}, 1 \mathrm{H}, \mathrm{OH}), 8.28(\mathrm{~s}, 1 \mathrm{H}, \mathrm{OH}), 7.34(\mathrm{~d}, J=8.6 \mathrm{~Hz}$, $\left.2 \mathrm{H}, \mathrm{C}_{6} \mathrm{H}_{4}\right), 7.17\left(\mathrm{~d}, J=8.6 \mathrm{~Hz}, 2 \mathrm{H}, \mathrm{C}_{6} \mathrm{H}_{4}\right), 7.13\left(\mathrm{~d}, J=8.8 \mathrm{~Hz}, 2 \mathrm{H}, \mathrm{C}_{6} \mathrm{H}_{4}\right), 7.09$ (d, J = $8.5 \mathrm{~Hz}$, $\left.2 \mathrm{H}, \mathrm{C}_{6} \mathrm{H}_{4}\right), 7.05\left(\mathrm{~d}, J=8.7 \mathrm{~Hz}, 2 \mathrm{H}, \mathrm{C}_{6} \mathrm{H}_{4}\right), 6.92\left(\mathrm{~d}, J=8.6 \mathrm{~Hz}, 2 \mathrm{H}, \mathrm{C}_{6} \mathrm{H}_{4}\right), 6.83(\mathrm{~d}, J=8.5 \mathrm{~Hz}$, $\left.2 \mathrm{H}, \mathrm{C}_{6} \mathrm{H}_{4}\right), 6.73\left(\mathrm{~d}, J=8.7 \mathrm{~Hz}, 2 \mathrm{H}, \mathrm{C}_{6} \mathrm{H}_{4}\right), 6.42(\mathrm{dt}, J=4.8,2.3 \mathrm{~Hz}, 2 \mathrm{H}, \mathrm{CpRe}), 5.82(\mathrm{dt}, J=3.8$, $2.3 \mathrm{~Hz}, 2 \mathrm{H}, \mathrm{CpRe}$ ), 4.14 (s, 5H, Cp), 4.13 (s, 5H, Cp), 4.13 - 3.78 (m, 4H, subst. Cp), 2.64 (q, $\left.\mathrm{J}=7.4 \mathrm{~Hz}, 2 \mathrm{H}, \mathrm{CH}_{2}\right), 1.04\left(\mathrm{t}, J=7.4 \mathrm{~Hz}, 3 \mathrm{H}, \mathrm{CH}_{3}\right)$.

${ }^{13} \mathrm{C}$ NMR (75 MHz, Acetone-d6) $\delta 193.5$ (C-O0R), 162.9 (C), 156.9 (C), 149.6 (C), 144.2 (C), 143.9(C), 136.7 (C), 131.7 (2 CH, $\left.\mathrm{C}_{6} \mathrm{H}_{4}\right), 131.2$ (2 CH, $\left.\mathrm{C}_{6} \mathrm{H}_{4}\right), 122.1$ (2 CH, $\left.\mathrm{C}_{6} \mathrm{H}_{4}\right), 116.0$ (2 $\mathrm{CH}, \mathrm{C}_{6} \mathrm{H}_{4}$ ), 90.9 (2 CH, CpRe), $88.4\left(\mathrm{C}_{\mathrm{q}}, \mathrm{CpRe}\right.$ ), 87.4 ( $\mathrm{C}_{\mathrm{q}}, \mathrm{CpFe}$ ), 87.7 (2 CH, CpRe), 70.0 (2 CH, subst. CpFe), 69.9 (5 CH, CpFe), 68.9 (2 CH, subst. CpFe), $28.6\left(\mathrm{CH}_{2}\right), 15.8\left(\mathrm{CH}_{3}\right)$. IR [cm-1]: 3390, 311, 2971, 2925, 2860, 2030, 1929, 1740, 1608, 1509, 1461, 1280, 1165, 820.

IR $v\left(\mathrm{~cm}^{-1}\right) 3115,2972,2030,1929,1740,1608,1509,1461,1280$

MS-CI (NH3) m/z: $787.21(\mathrm{M}+\mathrm{H})^{+}, 804.26\left(\mathrm{M}+\mathrm{NH}_{4}\right)^{+}, 425.1(\mathbf{1 a}+\mathrm{H})^{+}$.

HR-MS (ESI) m/z calcd for $\mathrm{C}_{35} \mathrm{H}_{27} \mathrm{FeO}_{6} \mathrm{Re} 786.0709$; found 786.0708 (M)+

EA : $\mathrm{C}_{35} \mathrm{H}_{27} \mathrm{FeO}_{6} \mathrm{Re} \bullet\left(\mathrm{CH}_{3} \mathrm{CN}\right)_{2}$ calc.: C, 53.98; H, 3.83. found : C, 54.29; H, 4.00

\section{$(Z+E)-5$ and 6}

Compound 2 (0.86 g, $1.9 \mathrm{mmol})$ was dissolved in THF $(100 \mathrm{~mL})$. Sodium hydride $(0.05 \mathrm{~g}$, $2.0 \mathrm{mmol}$ ) was added in small portions. After 30 minutes of stirring at room temperature, a solution of $8(0.8 \mathrm{~g}, 1.9 \mathrm{mmol})$ in THF (30 mL) was added. The mixture was stirred for 3 days at room temperature and then heated $30 \mathrm{~min}$ to boiling point followed by two washings with $0.5 \mathrm{M} \mathrm{HCl}(100 \mathrm{~mL})$ and once with saturated sodium chloride solution. The crude product was first purified by column chromatography on silica gel (DCM/acetone 20:1, $\mathrm{R}_{\mathrm{f}}$ values $=0.15$ and 0.2 ) followed by preparative RPHPLC affording 5 (14 mg, $0.017 \mathrm{mmol}, 1 \%$ yield) and 6 (38 mg, $0.047 \mathrm{mmol}, 3 \%$ yield) as red-brown solids. Complex $\mathbf{5}$ was a mixture of E/Z-isomers (the ratio of two isomers was around 2.5:1 according to ${ }^{1} \mathrm{H} \mathrm{NMR}$ ). 
2-Ferrocenyl-1-(4-hydroxyphenyl)-1-(( $n$-5-phenyloxycarbonylcyclopentadienyl)-

tricarbonylrhenium(I))-5-hydroxy-pent-1-ene $(\mathbf{Z}+\boldsymbol{E})-5$

${ }^{1} \mathrm{H}$ NMR (300 MHz, Acetone-d 6$) \delta 8.30(\mathrm{~s}, 1 \mathrm{H}, \mathrm{OH}), 8.27$ (s, 1H, OH), 7.33 (d, J = $8.5 \mathrm{~Hz}$, $\left.2 \mathrm{H}, \mathrm{C}_{6} \mathrm{H}_{4}\right), 7.16\left(\mathrm{~d}, \mathrm{~J}=8.5 \mathrm{~Hz}, 2 \mathrm{H}, \mathrm{C}_{6} \mathrm{H}_{4}\right), 7.12\left(\mathrm{~d}, \mathrm{~J}=8.5 \mathrm{~Hz}, 2 \mathrm{H}, \mathrm{C}_{6} \mathrm{H}_{4}\right), 7.09$ (d, J = $8.4 \mathrm{~Hz}$, $\left.2 \mathrm{H}, \mathrm{C}_{6} \mathrm{H}_{4}\right), 7.05\left(\mathrm{~d}, \mathrm{~J}=8.7 \mathrm{~Hz}, 2 \mathrm{H}, \mathrm{C}_{6} \mathrm{H}_{4}\right), 6.91\left(\mathrm{~d}, \mathrm{~J}=8.5 \mathrm{~Hz}, 2 \mathrm{H}, \mathrm{C}_{6} \mathrm{H}_{4}\right), 6.82(\mathrm{~d}, \mathrm{~J}=8.5 \mathrm{~Hz}$, $\left.2 \mathrm{H}, \mathrm{C}_{6} \mathrm{H}_{4}\right), 6.73\left(\mathrm{~d}, \mathrm{~J}=8.5 \mathrm{~Hz}, 2 \mathrm{H}, \mathrm{C}_{6} \mathrm{H}_{4}\right), 6.46-6.39(\mathrm{~m}, 2 \mathrm{H}, \mathrm{CpRe}), 5.81(\mathrm{t}, \mathrm{J}=2.4 \mathrm{~Hz}, 2 \mathrm{H}$, CpRe), 4.15 (s, 5H, Cp), 4.14 (s, 5H, Cp), $4.11-4.06$ (m, 2H, subst. Cp), 4.01 (t, J = 1.9 Hz, 2H, subst. Cp), 3.98 (t, J = 1.9 Hz, 2H, subst. Cp), 3.45 (t, J = 5.0 Hz, 2H, $\mathrm{CH}_{2}$ ), $2.78-2.66$ $\left(\mathrm{m}, 2 \mathrm{H}, \mathrm{CH}_{2}\right), 1.76-1.60\left(\mathrm{~m}, 2 \mathrm{H}, \mathrm{CH}_{2}\right)$.

${ }^{13} \mathrm{C}$ NMR (75 MHz, Acetone- $\mathrm{d}_{6}$ ) $\delta 193.6$ (COOR), 149.6 (C), 144.3 (C), 143.9(C), 138.0 (C), 136.8 (C), 136.6 (C), 131.7 (2 CH, $\left.\mathrm{C}_{6} \mathrm{H}_{4}\right), 131.2$ (2 $\left.\mathrm{CH} \mathrm{C}_{6} \mathrm{H}_{4}\right), 122.1$ (2 CH, $\left.\mathrm{C}_{6} \mathrm{H}_{4}\right), 116.0(2$ $\mathrm{CH}, \mathrm{C}_{6} \mathrm{H}_{4}$ ), 90.9 (2 CH, CpRe), 88.4 (C $\mathrm{C}_{\mathrm{q}}, \mathrm{CpRe}$ ), 87.8 (C $\mathrm{C}, \mathrm{CpFe}$ ), 87.7 (2 CH, CpRe), 70.2 (2 CH, subst. CpFe), 69.9 (5 CH CpFe), 68.9 (2 CH subst. CpFe), $62.5\left(\mathrm{CH}_{2}\right), 34.8\left(\mathrm{CH}_{2}\right), 31.9$ $\left(\mathrm{CH}_{3}\right)$.

IR $v\left(\mathrm{~cm}^{-1}\right) 3110,2935,2029,1927,1739,1610,1509,1461,1281$.

MS-CI $\left(\mathrm{NH}_{3}\right) \mathrm{m} / \mathrm{z}: 817.17(\mathrm{M}+\mathrm{H})^{+}, 834.24\left(\mathrm{M}+\mathrm{NH}_{4}\right)^{+}$

HR-MS (ESI) m/z calcd for $\mathrm{C}_{36} \mathrm{H}_{29} \mathrm{FeO}_{7} \mathrm{Re}$ 816.0815; found 816.0817 (M)+

2-Ferrocenyl-1,1-bis(4-hydroxyphenyl)-pent-1-enyl-( 7 -5-oxycarbonyl-cyclopentadienyl)tricarbonylrhenium(I) 6

${ }^{1} \mathrm{H} \mathrm{NMR}(300 \mathrm{MHz}$, Acetone-d 6 ) $\delta 8.27$ (s, 1H, OH), 8.19 (s, 1H, OH), 7.08 (d, J = $8.5 \mathrm{~Hz}$, $\left.2 \mathrm{H}, \mathrm{C}_{6} \mathrm{H}_{4}\right), 6.89\left(\mathrm{~d}, \mathrm{~J}=8.5 \mathrm{~Hz}, 2 \mathrm{H}, \mathrm{C}_{6} \mathrm{H}_{4}\right), 6.83\left(\mathrm{~d}, \mathrm{~J}=8.5 \mathrm{~Hz}, 2 \mathrm{H}, \mathrm{C}_{6} \mathrm{H}_{4}\right), 6.71$ (d, J = $8.5 \mathrm{~Hz}$, $\left.2 \mathrm{H}, \mathrm{C}_{6} \mathrm{H}_{4}\right), 6.04(\mathrm{t}, \mathrm{J}=2.3 \mathrm{~Hz}, 2 \mathrm{H}, \mathrm{CpRe}), 5.71(\mathrm{t}, \mathrm{J}=2.3 \mathrm{~Hz}, 2 \mathrm{H}, \mathrm{CpRe}), 4.13$ (s, 5H, Cp), 4.08 (t, J = 1.9 Hz, 2H, subst. Cp), 3.97 (t, J = 1.9 Hz, 2H, subst. Cp), $2.81-2.75$ (m, 2H, $\left.\mathrm{CH}_{2}\right), 2.12-2.04\left(\mathrm{~m}, 2 \mathrm{H}, \mathrm{CH}_{2}\right), 1.9\left(\mathrm{~m}, 2 \mathrm{H}, \mathrm{CH}_{2}\right)$.

${ }^{13} \mathrm{C}$ NMR (75 MHz, Acetone-d 6 ) $\delta 193.8$ (C-OOR), 164.12 (C-OH), 156.8 (C-OH), 139.8 (C), 137.3 (C), 137.2 (C), $134.4(\mathrm{C}), 131.8\left(2 \mathrm{CH} \mathrm{C}_{6} \mathrm{H}_{4}\right), 131.4\left(2 \mathrm{CH} \mathrm{C}_{6} \mathrm{H}_{4}\right), 116.1$ (2 CH $\left.\mathrm{C}_{6} \mathrm{H}_{4}\right), 115.9$ (2 $\mathrm{CH} \mathrm{C}_{6} \mathrm{H}_{4}$ ), 90.3 (2 CH, CpRe), 89.9 ( $\left.\mathrm{C}_{\mathrm{q}}, \mathrm{CpRe}\right), 88.1\left(\mathrm{C}_{\mathrm{q}}, \mathrm{CpFe}\right), 87.1$ (2 CH CpRe), 70.0 (2 CH, subst. CpFe), 69.9 (5 CH, CpFe), 68.8 (2 CH, subst. CpFe), 65.8 ( $\left.\mathrm{CH}_{2}-\mathrm{O}\right)$ ), $32.1\left(\mathrm{CH}_{2}-\mathrm{C}=\mathrm{C}\right), 30.3\left(\mathrm{CH}_{2}\right)$.

IR $v\left(\mathrm{~cm}^{-1}\right) 3390,3111,2926,2854,2027,1929,1698,1607,1508,1471,1287,1166$, 834. 
MS-CI $\left(\mathrm{NH}_{3}\right) \mathrm{m} / \mathrm{z}: 817.26(\mathrm{M}+\mathrm{H})^{+}, 834.18\left(\mathrm{M}+\mathrm{NH}_{4}\right)^{+}$.

HR-MS (ESI) m/z calcd for $\mathrm{C}_{36} \mathrm{H}_{29} \mathrm{FeO}_{7} \mathrm{Re} 816.0815$; found 816.0816 (M)+

\section{Biological Evaluation}

\section{Partition coefficients}

Measurement of the octanol/water partition coefficient ( $\log \mathrm{P}_{\mathrm{o} / \mathrm{w}}$ ) was made by HPLC technique according to the method previously described. ${ }^{24,25}$ Measurement of the chromatographic capacity factors $(\mathrm{k})$ for each molecule was done at various concentrations in the range 95-75\% methanol containing $0.25 \% 1$-octanol $(\mathrm{v} / \mathrm{v})$ and aqueous phase consisting of $0.15 \% \mathrm{n}$-decylamine $(\mathrm{v} / \mathrm{v})$ in the buffering agent MOPS prepared in 1-octanol saturated water, adjusted to $\mathrm{pH}$ 7.4. These capacity factors ( $\left.\mathrm{k}^{\prime}\right)$ are extrapolated to $100 \%$ of the aqueous component given the value of $\mathrm{k}_{\mathrm{w}}^{\prime}$. The $\log \mathrm{P}_{\mathrm{o} / \mathrm{w}}$ is obtained by the formula $\log \mathrm{P}_{\mathrm{o} / \mathrm{w}}=0.31418+0.98452 \log \mathrm{k}^{\prime}$.

\section{Cell culture}

Stock solutions $(10 \mathrm{mM})$ of the compounds to be tested were prepared in DMSO and were kept at $-20^{\circ} \mathrm{C}$ in the dark. Serial dilutions in Dubelcco's modified Eagle's medium (DMEM) without phenol red/Glutamax I were prepared just prior to use. DMEM without phenol red, Glutamax I and fetal bovine serum (FBS) were purchased from Life Technologies, hormone independent breast cancer cells, MDA-MB-231, cells were purchased from ATCC (Manassas, VA, USA). Cells were maintained in a monolayer culture in DMEM with phenol red/Glutamax I supplemented with $9 \% \mathrm{FBS}$ at $37^{\circ} \mathrm{C}$ in a $5 \% \mathrm{CO}_{2}$ /air humidified incubator. For study of the cytotoxicity of the complexes (determination of IC $_{50}$ values of the complexes), MDA-MB-231 cells were plated in $1 \mathrm{~mL}$ of DMEM without phenol red, supplemented with $9 \%$ decomplemented and hormone depleted FBS, 1\% kanamycin, 1\% Glutamax and incubated for $24 \mathrm{~h}$. The following day (D0), $1 \mathrm{~mL}$ of the same medium containing the compounds to be tested was added to the plates (final volume of DMSO = $0.1 \%$ ). After 3 days (D3) the incubation medium was removed and $2 \mathrm{~mL}$ of fresh medium containing the compounds was added. At D5 the protein content of each well was quantified by methylene blue staining as follows: cell monolayers were fixed for $1 \mathrm{~h}$ at room temperature with methylene blue $(1 \mathrm{mg} / \mathrm{mL}$ in 50:50 water/MeOH mixture) then washed with water. After addition of $\mathrm{HCl}(0.1 \mathrm{M}, 2$ $\mathrm{mL}$ ), the plate is incubated for $1 \mathrm{~h}$ at $37^{\circ} \mathrm{C}$ and then the absorbance of each well (4 wells 
for each concentration) was measured at $655 \mathrm{~nm}$ with a Fluorostar microplate reader (BMG Labtech). The results are expressed as the percentage of proteins versus the control. Two independent experiments with run in quadruplicate were performed.

\section{Enzymatic oxidation of the compounds by the $\mathrm{HRP} / \mathrm{H}_{2} \mathrm{O}_{2}$ mixture}

Oxidation of the compounds $(50 \mu \mathrm{M})$ by $\mathrm{HRP}(46 \mathrm{nM})$ and $\mathrm{H}_{2} \mathrm{O}_{2}(200 \mu \mathrm{M})$ was performed at pH 8.1 in $0.2 \mathrm{M}$ Tris-HCl, 1 mM EDTA containing 10\% DMSO. HRP (40 $\mu \mathrm{L}$ of $1.1 \mu \mathrm{M}$ solution) and $\mathrm{H}_{2} \mathrm{O}_{2}$ (20 $\mu \mathrm{L}$ of $10 \mathrm{mM}$ solution) were pre-incubated for $5 \mathrm{~min}$ and then added to the solution of the compounds $(940 \mu \mathrm{L})$. The mixture was immediately transferred to a cuvette and the UV-Visible spectrum was recorded between 250 and $700 \mathrm{~nm}$ every 30 s on a Cary 50 spectrometer (Varian, Palo Alto, CA, USA). Rate constants $\mathrm{k}_{\mathrm{obs}}$ were calculated using Kaleidagraph software by fitting $\mathrm{OD}_{376 \mathrm{~nm}}$ (4), $\mathrm{OD}_{350 \mathrm{~nm}}(5), \mathrm{OD}_{568 \mathrm{~nm}}(6)$ or $\mathrm{OD}_{563 \mathrm{~nm}}(2)$ versus time data according to the first order law equation: $\mathrm{OD}=\mathrm{C}_{0}+\mathrm{C}_{1} \exp \left(-\mathrm{k}_{\mathrm{obs}} \mathrm{x} \mathrm{t}\right)$.

\section{Determination of cellular content of 5 or 6 in MDA-MB-231 cells by transmission FT-IR spectroscopy.}

MDA-MB-231 cells were seeded in $25 \mathrm{~cm}^{2}$ flasks at a density so as to reach confluency after $24 \mathrm{~h}$. Cells were washed with 1x D-PBS and fresh growth medium (charcoaldesteroided DMEM, $5 \mathrm{ml})$ containing various concentrations of 5 or $6(10,25$ or $50 \mu \mathrm{M})$ prepared from the $10 \mathrm{mM}$ DMSO stock solutions was added. Control cells (no complex) were run simultaneously. Cells were incubated at $37^{\circ} \mathrm{C}$ under a humidified atmosphere of $95 \%$ air / $5 \% \mathrm{CO}_{2}$ for 25 or $60 \mathrm{~min}$. Some experiments were also run at $4^{\circ} \mathrm{C}$. At the end of the incubation, the medium was discarded and cells were washed with D-PBS. Trypsin (1x trypsin-EDTA, $0.05 \%$ trypsin, $0.53 \mathrm{mM}$ EDTA, $1 \mathrm{ml}$ ) was added and cells were incubated $5 \mathrm{~min}$ at $37^{\circ} \mathrm{C}$ in a humidified atmosphere of 95\% air / 5\% $\mathrm{CO}_{2}$. D-PBS $(5 \mathrm{ml})$ was added to quench the action of trypsin. The suspension was centrifuged $(520 \mathrm{~g}$, $5 \mathrm{~min}$ ) and the supernatant discarded. After re-suspension in D-PBS ( $5 \mathrm{ml}$ ), the number of cells was estimated by visual counting in a Mallassez chamber $(10 \mu \mathrm{l})$. The remaining suspension was centrifuged (520g, $5 \mathrm{~min}$ ), the supernatant discarded and a volume of DPBS was added to reach ca. $10^{5}$ cells per $10 \mu \mathrm{l}$. Another $10 \mu \mathrm{l}$ of the suspension was diluted to $1 / 50$ and cells were counted again in the Mallassez chamber to determine the exact number of cells deposited on the nitrocellulose disks ( $6 \mathrm{~mm}$-diameter). The disks 
were allowed to dry in air (ca. $2 \mathrm{~h}$ ). Experiments were done in duplicate for each concentration and for each concentration, two nitrocellulose disks were produced to check the reproducibility of the procedure. Transmission FT-IR spectra were recorded at $4 \mathrm{~cm}^{-1}$ with 48 scans and subtracted from the IR spectrum of a disk covered with control cells. The absorbance of the band at $2029 \mathrm{~cm}^{-1}$ was used for quantification using a calibration curve established by spotting solutions of 5 or $\mathbf{6}$ at known concentration in isopropanol on nitrocellulose disks (Figure S7).

\section{ICP-EOS analysis}

MDA-MB-231 cells were seeded in $100 \mathrm{~mm}$ Petri dishes at a density so as to reach confluency after $24 \mathrm{~h}$. Cells were washed with 1x D-PBS and fresh growth medium (charcoal-desteroided DMEM, $5 \mathrm{ml}$ ) containing $50 \mu \mathrm{M}$ of 5 or $25 \mu \mathrm{M}$ of 6 prepared from the $10 \mathrm{mM}$ DMSO stock solutions was added. Cells were incubated for $60 \mathrm{~min}$ at $37^{\circ} \mathrm{C}$ under a humidified atmosphere of $95 \%$ air / $5 \% \mathrm{CO}_{2}$. At the end of the incubation, the medium was removed and cells were washed with D-PBS $(10 \mathrm{ml})$. Trypsin (1x trypsinEDTA, $0.05 \%$ trypsin, $0.53 \mathrm{mM}$ EDTA, $1 \mathrm{ml}$ ) was added and cells were incubated $5 \mathrm{~min}$ at $37^{\circ} \mathrm{C}$ in a humidified atmosphere of $95 \%$ air $/ 5 \% \mathrm{CO}_{2}$. D-PBS ( $5 \mathrm{ml}$ ) was added to quench the action of trypsin. The suspension was centrifuged (520g, $5 \mathrm{~min}$ ) and the supernatant discarded. After re-suspension in D-PBS $(2 \mathrm{ml})$, the number of cells was estimated by visual counting in a Mallassez chamber $(10 \mu \mathrm{l})$. The suspension was centrifuged again, the supernatant discarded and the cell pellet was taken up into $0.6 \mathrm{ml}$ $\mathrm{HNO}_{3} 70 \%$. The cells were digested at $60^{\circ} \mathrm{C}$ in an ultrasound bath for $180 \mathrm{~min}$. The sample was adjusted to $4 \% \mathrm{HNO}_{3}$ by addition of water and filtered on a $0.2 \mu \mathrm{m}$ syringe filter. The culture medium was diluted to $1 / 2$ with $4 \% \mathrm{HNO}_{3}$. Quantification of Fe and $\mathrm{Re}$ was performed by ICP-OES at 238.204 and $221.426 \mathrm{~nm}$, respectively. The results are the mean of three measurements.

\section{AFM-IR measurements.}

MDA-MB-231 cells were grown on $\mathrm{CaF}_{2}$ thin slides (from Crystran, diameter $10 \mathrm{~mm}$; thickness $0.1 \mathrm{~mm}$ ), then incubated at $37^{\circ} \mathrm{C}$ for $1 \mathrm{~h}$ in the presence of $10 \mu \mathrm{M}$ solution of 6 (final volume of DMSO $=0.1 \%$ ) under an atmosphere of $95 \%$ air $/ 5 \% \mathrm{CO}_{2}$. At the end of the incubation the medium was removed and the cells were washed twice with 
phosphate buffer (D-PBS, $2 \times 2 \mathrm{~mL}$ ). The cells were fixed with 4\% para-formaldehyde $(1.5 \mathrm{~mL})$ for $8 \mathrm{~min}$ at room temperature and washed once with D-PBS ( $1 \times 2 \mathrm{~mL})$ and once with pure water. Slides were air-dried and laid on the upper surface of a $\mathrm{CaF}_{2}$ prism (angle $50^{\circ}$ ) with paraffin oil in between to make a good optical contact and avoid evanescent waves in the air gap. All measurements have been done by the nanoIR $1^{\mathrm{TM}}$ (Anasys Instruments), a microscope based on the AFM-IR technique. This technique combines atomic force microscopy with pulsed tunable infrared laser to perform infrared spectroscopy and imaging at the nanoscale. The sample is placed on an IR transparent prism $\left(\mathrm{CaF}_{2}\right)$ and irradiated with a pulsed nanosecond tunable laser in total reflection configuration to avoid tip illumination. If the IR laser is tuned to a wavenumber corresponding to sample absorption band, the absorbed light is transformed into heat. This fast heating (nanosecond) results in a rapid thermal expansion localized only in the absorption region. The thermal expansion is then detected by the tip of the AFM as a shock, causing the cantilever to oscillate at its own resonance modes. Because of damping due to surface contact, this oscillation will decrease as a function of time (ring down). The four-quadrant detector of the AFM finally records these oscillations. Thus, the detection scheme is analogous to photoacoustic spectroscopy, except that AFM tip and cantilever are used to detect and amplify the thermal expansion signal instead of a microphone in a gas cell. ${ }^{26}$ Because the oscillation amplitude detected by the AFM is rigorously proportional to the local absorption, recording the oscillation maxima at one tip position as a function of laser wavenumber allows the build up of local IR absorption spectra which correlate very well to conventional IR absorption spectra collected in transmission. In addition, mapping the oscillation amplitudes at specific wavenumbers, gives a spatially resolved map of IR absorption allowing localization of chemical functional groups. The spatial resolution of the AFM-IR microscope is around $50-100 \mathrm{~nm}$ and the spectral resolution as determined by the natural line-width of the pulsed IR laser source is about $6 \mathrm{~cm}^{-1}$. Technical characteristics of the AFM-IR system are the following: the IR laser is an optical parametric oscillator (OPO) which produces 10 ns pulses tunable between 4000 and $1000 \mathrm{~cm}^{-1}$ with a repetition rate of $1 \mathrm{kHz}$. Between 1800 and $1500 \mathrm{~cm}^{-1}$, the laser spot size was around $50 \mu \mathrm{m}$, and the power was fixed at $3 \mu \mathrm{J}$ per pulse. Local spectra were collected using a $2 \mathrm{~cm}^{-1}$ step size, and an average of 256 pulses were co-added for each 
data point. Topographic images were acquired in contact mode with cantilevers of 0.03 $\mathrm{N} / \mathrm{m}(\mu \mathrm{masch} \mathrm{HQ}: \mathrm{CSC} / \mathrm{AlBS})$.

\section{Results and Discussion}

\section{Synthesis of complexes 4, 5 and 6}

Cyclopentadienyltricarbonylrhenium(I)carboxylic acid 7 was prepared by the thermal reaction of $\operatorname{Re}_{2}(\mathrm{CO})_{10}$ with cyclopentadiene carboxylic acid in mesitylene as described in ref. ${ }^{23}$, then transformed into its acyl chloride 8 by reaction with oxalyl chloride (Scheme 1).

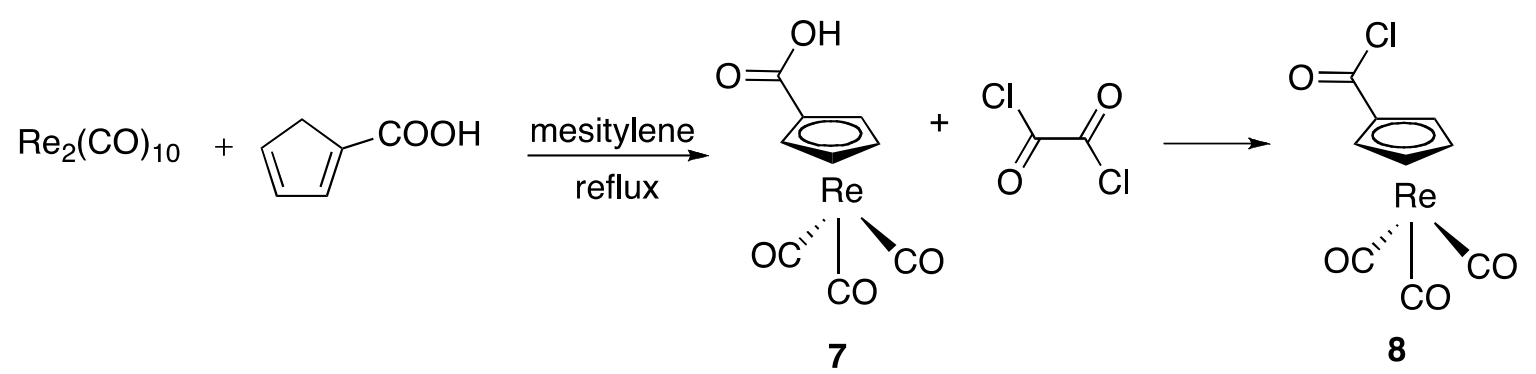

Scheme 1 : Synthesis of 8

Complex 4 was obtained by acylation of $\mathbf{1 a}$ with $\mathbf{8}$ in the presence of DMAP and DIPEA (Scheme 2). The reaction was slow (4 days) and $\mathbf{4}$ was obtained as a mixture of $Z$ and $E$ isomers in $20 \%$ yield.

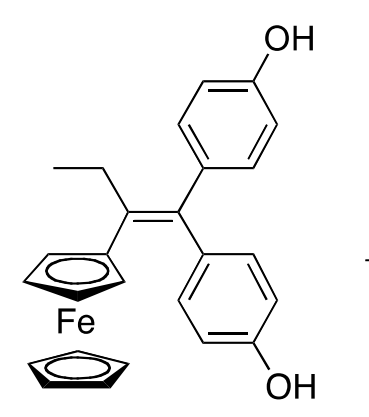

$1 a$

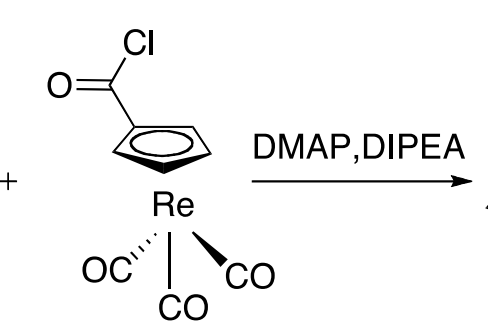

8

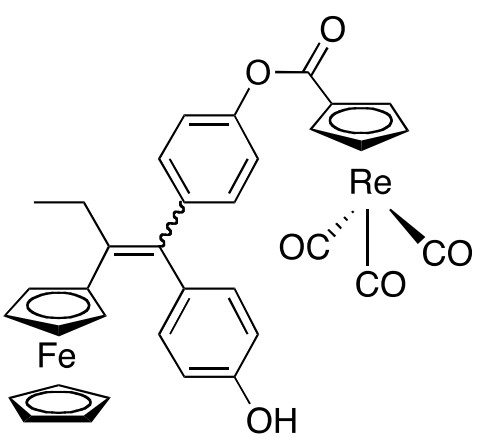

$(Z+E)-4$

Scheme 2 : Synthesis of 4

As complex 2 possesses two types of hydroxyl groups, an aliphatic and an aromatic one, $\mathbf{5}$ and $\mathbf{6}$ were prepared by esterification of complex $\mathbf{2}$ in the presence of $\mathrm{NaH}$ and 8, (Scheme 3). Reaction was slow and afforded a mixture of $(Z+E)-\mathbf{5}$ isomers and $\mathbf{6}$ as well as other byproducts. After purification by silica gel column chromatography followed by preparative RP-HPLC, complexes $(Z+E)-\mathbf{5}$ and $\mathbf{6}$ were obtained in low yield. 


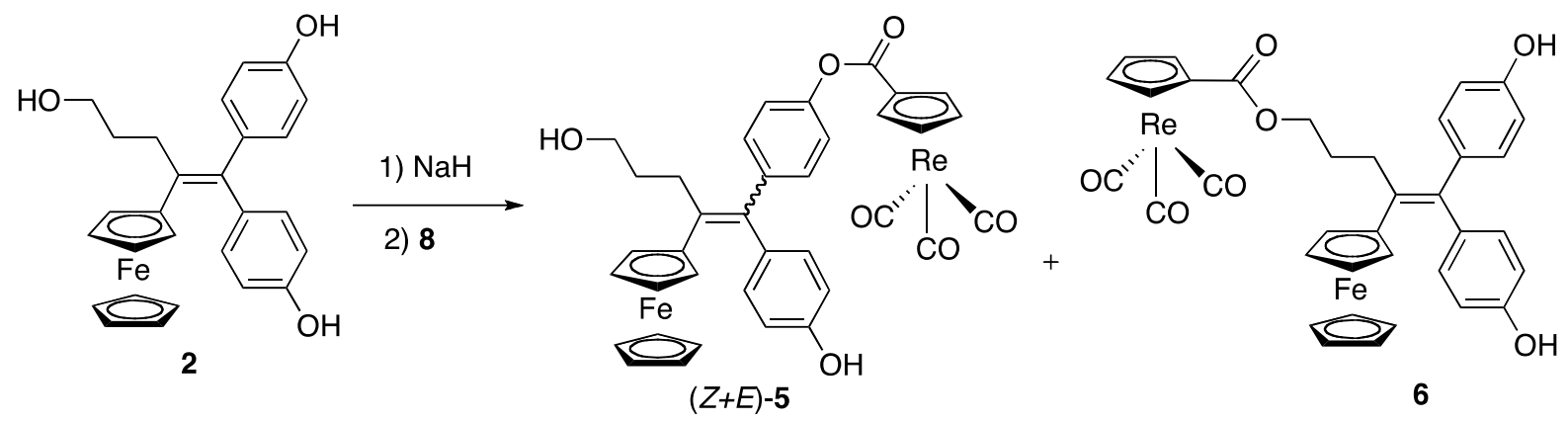

Scheme 3 : Synthesis of 5 and 6

The ATR-IR spectrum of compounds 4, 5 and $\mathbf{6}$ displays two intense bands at 2030 and $1929 \mathrm{~cm}^{-1}$ for 4 and 5 or 2027 and $1929 \mathrm{~cm}^{-1}$ for $\mathbf{6}$, readily assigned to the symmetric (A1) and asymmetric (E) stretching vibration modes of the CO ligands, respectively (Fig. S4-S6). These features will be used for further infrared studies.

\section{Biochemical studies}

Evaluation of the lipophilicity of the complexes

Partition coefficients of the newly synthesized rhenium complexes were measured as described previously ${ }^{22}$ and are reported in Table 1 . These values are compared with that of their ferrocifen precursors (1a and 2). As expected, ${ }^{27}$ addition of the $\mathrm{CpRe}(\mathrm{CO})_{3}$ tag enhanced the lipophilicity of the compounds $\left(\log \mathrm{P}_{\mathrm{o} / \mathrm{w}}\right.$ in the range 6.2- 7.6). This increase was almost the same for the three new complexes 4-6 (around 2.6).

Table 1 Lipophilicity values $\left(\log \mathrm{P}_{\mathrm{o}} \mathrm{w}\right)$ and $\mathrm{IC}_{50}$ values on MDA-MB-231 cancer cells for the complexes under study.

\begin{tabular}{|c|c|c|}
\hline Complex & $\log \mathrm{P}_{\mathrm{o} / \mathrm{w}}$ & $\mathrm{IC}_{50}(\mu \mathrm{M})^{\mathrm{a})}$ \\
\hline $\mathbf{1 a}$ & $5.0^{\mathrm{b})}$ & $0.66 \pm 0.06^{\mathrm{b})}$ \\
\hline $\mathbf{2}$ & $4.2^{\mathrm{c})}$ & $0.11 \pm 0.02^{\mathrm{c})}$ \\
\hline$(Z+E)-\mathbf{4}$ & $7.6(Z, E)$ & $2.3 \pm 0.3$ \\
\hline$(Z+E)-\mathbf{5}$ & $6.2,6.7(Z, E)$ & $0.32 \pm 0.03$ \\
\hline $\mathbf{6}$ & 6.8 & $2.5 \pm 0.4$ \\
\hline
\end{tabular}

a) after 5 days of culture, mean of two independent experiments ; b) value from ref ${ }^{28}$; c) value from ref 2

These complexes, which possess two lipophilic organometallic units, namely ferrocenyl and cyrhetrenyl units have the highest $\log \mathrm{P}_{\mathrm{o}}$ w values ever found in the ferrocifen family. For comparison, the previously studied cyrhetrenyl ferrocifen $\mathbf{3}$ is also 
highly lipophilic $\left(\log \mathrm{P}_{\mathrm{o} / \mathrm{w}}=5.6\right) \cdot{ }^{19}$ Consequently, these molecules rapidly enter cells (Table 3).

Antiproliferative activity of the complexes on breast cancer cells (MDA-MB-231)

$\mathrm{IC}_{50}$ values of complexes $\mathbf{4}-\mathbf{6}$ have been evaluated on the hormone independent breast cancer cell line MDA-MB-231 (Table 1). As can be deduced from the $\mathrm{IC}_{50}$ values, conjugation of a cyrhetrenyl entity to $\mathbf{1 a}$ and $\mathbf{2}$ decreased their cytotoxicity to some extent. Moreover, since these complexes are esters, their hydrolysis to regenerate the parent ferrocifens $\mathbf{1 a}$ and $\mathbf{2}$ in the cellular medium cannot be completely ruled out. However, such a hydrolysis did not appear to take place for compounds $\mathbf{4}$ and $\mathbf{6}$ since their $\mathrm{IC}_{50}$ value is significantly higher than that of their precursors (2.3 and 2.5 versus 0.66 and $0.11 \mu \mathrm{M}$, respectively). In the series, compound 5 shows the lowest IC $_{50}(0.32$ $\mu \mathrm{M})$ but it is still three times higher than that of its precursor $(0.11 \mu \mathrm{M})$. Its high cytotoxicity can be associated with the fact that its oxidation can lead, as for its parent complex 2, to a tetrahydrofuran-substituted quinone methide (Scheme S2), which is assumed to be very reactive. ${ }^{2,29}$

Enzymatic oxidation of compounds with horseradish peroxidase (HRP)/ $\mathrm{H}_{2} \mathrm{O}_{2}$

The three cyrhetrenyl-tagged ferrocifens 4-6, their ferrocifen precursors $1 \mathrm{a}$ and 2 and $\mathbf{1 b}$ were submitted to enzymatic oxidation with $\mathrm{HRP} / \mathrm{H}_{2} \mathrm{O}_{2}$ mixture at $\mathrm{pH} 8.1$ and the reaction was monitored by UV-visible spectrometry (Fig. S9-S13). Table 2 summarizes the results obtained for these enzymatic oxidation experiments. Solutions of diphenols $1 \mathrm{a}, 2$, and 6 treated by $\mathrm{HRP} / \mathrm{H}_{2} \mathrm{O}_{2}$ mixture led to the immediate formation of pink products with absorption bands at $560,566,571 \mathrm{~nm}$ respectively. The same experiment performed at pH 5.0 led to the appearance of a band at $425 \mathrm{~nm}$. Such a pHdependent behaviour was previously observed during the enzymatic oxidation of ansaferrociphenol. ${ }^{30}$ This feature was assigned to the formation of a quinone methide (Scheme S1), which can be in its neutral (phenol) yellow form at acidic pH or in its anionic (phenolate) pink form at basic pH. Interestingly while the ferrocenyl QMs, 1a$\mathbf{Q M}$ and 2-QM, appeared to be very unstable (half-life = 5 and $12 \mathrm{~min}$ respectively), the ferrocenyl/cyrhetrenyl QM, 6-QM, was found to be stable at least for up to $60 \mathrm{~min}$ (Table 2). This increase of stability may be attributed to an intramolecular interaction between the oxygen atom of one of the CO ligands of the $\operatorname{Re}(\mathrm{CO})_{3}$ unit with the $\pi$-system 
(electron cloud) of the arene ring. This type of stabilization has been previously described. 31,32

Enzymatic oxidation of $\mathbf{4}$ and $\mathbf{5}$ led to a slight increase of absorbance between 350 and $450 \mathrm{~nm}$ with an isobestic point at $340 \mathrm{~nm}$ for 4 and $315 \mathrm{~nm}$ for $\mathbf{5}$. This evolution is reminiscent of that of $\mathbf{1 b}$ for which the corresponding QM displayed a maximum of absorption at $368 \mathrm{~nm}$ (Fig. S12). ${ }^{5}$ However, due to the strong absorbance of the cyrhetrenyl moiety around $370 \mathrm{~nm}$, we observed only an increase of absorbance for $\mathbf{4}$ and $\mathbf{5}$ and not a well identified peak as for $\mathbf{1 b}$. Nonetheless, attribution of these entities to QM is plausible. As observed for $\mathbf{6}$, the oxidized species formed from $\mathbf{4}$ and $\mathbf{5}$ are more stable than the QM obtained from their parent compounds $\mathbf{1 a}$ and $\mathbf{2}$ but as stable as that of the monophenolic complex $\mathbf{1 b}$. On the whole, these results evidence a marked stability of the oxidation products of the rhenium complexes.

Table 2 Enzymatic oxidation of the complexes with $\mathrm{HRP} / \mathrm{H}_{2} \mathrm{O}_{2}$ a)

\begin{tabular}{|c|c|c|c|c|}
\hline & $\begin{array}{l}\text { Number of } \\
\text { phenols }\end{array}$ & $\begin{array}{l}\lambda_{\max } \\
(\mathrm{nm})\end{array}$ & $\begin{array}{c}\text { Rate constant of } \\
\text { oxidation }\left(\mathrm{k}_{\mathrm{obs}}\right)^{\mathrm{b}} \\
\left(\mathrm{min}^{-1}\right)\end{array}$ & $\begin{array}{c}\text { Half life of } \\
\text { oxidation product } \\
\text { (min) }\end{array}$ \\
\hline $1 \mathrm{a}$ & 2 & 560 & 2.46 & 12 \\
\hline 2 & 2 & 566 & 1.38 & 5 \\
\hline 4 & 1 & $\begin{array}{c}\text { Increase of } \\
\text { absorbance } \\
\text { between } 320 \\
\text { and } 450 \mathrm{~nm} \\
\end{array}$ & 0.36 & n.d. c) \\
\hline 5 & 1 & $\begin{array}{c}\text { Increase of } \\
\text { absorbance } \\
\text { between } 320 \\
\text { and } 450 \mathrm{~nm}\end{array}$ & 0.5 & $>120 \mathrm{~min}$ \\
\hline 6 & 2 & 571 & 1.38 & $>60$ \\
\hline $1 b$ & 1 & 368 & 0.22 & 122 \\
\hline
\end{tabular}

a) Complexes $(50 \mu \mathrm{M})$ were oxidized by $\mathrm{HRP}(46 \mathrm{nM})$ and $\mathrm{H}_{2} \mathrm{O}_{2}(200 \mu \mathrm{M})$ at pH 8.1 ; b) calculated from the spectroscopic data assuming a first order kinetics law; c) not determined due to side reactions

\section{Quantification of 5 or $\mathbf{6}$ in cancer cells by transmission FT-IR spectroscopy}

MDA-MB-231cells were incubated for $60 \mathrm{~min}$ at $37^{\circ} \mathrm{C}$ in the presence of various concentrations of 5 or $\mathbf{6}(10,25$ or $50 \mu \mathrm{M})$. At the end of the incubation time, adherent cells were detached and collected by centrifugation. They were counted and then deposited on nitrocellulose disks. After air-drying, the disks were analyzed by transmission FT-IR spectroscopy. The two characteristic bands of the $\operatorname{Re}(\mathrm{CO})_{3}$ unit, at 
2030 and $1940 \mathrm{~cm}^{-1}$ for 5 or 2030 and $1944 \mathrm{~cm}^{-1}$ for 6 were observed on the spectra (Fig. 1). Quantification was performed by calibration with 5 and 6 at $2029 \mathrm{~cm}^{-1}$ as previously published (Table 3$) .18$

Table 3. Quantification of 5 and $\mathbf{6}$ by FT-IR spectroscopy in MDA-MB-231 cells after incubation for $60 \mathrm{~min}$ at $37^{\circ} \mathrm{C}$ or at $4^{\circ} \mathrm{C}$ calculated from the absorbance at $2029 \mathrm{~cm}^{-1}$

\begin{tabular}{|c|c|c|c|c|}
\hline \multirow{2}{*}{$\begin{array}{c}\text { Incubation } \\
\text { concentration }(\mu \mathrm{M})\end{array}$} & \multicolumn{2}{|c|}{ Complex 5 (fmol/cell) } & \multicolumn{2}{c|}{ Complex 6 (fmol/cell) } \\
\cline { 2 - 5 } & $37^{\circ} \mathrm{C}$ & $4^{\circ} \mathrm{C}$ & $37^{\circ} \mathrm{C}$ & $4^{\circ} \mathrm{C}$ \\
\hline 10 & $3.3^{\mathrm{b}}$ & nd & $3.1 \pm 1.0$ & nd \\
\hline 25 & $4.5^{\mathrm{b}}$ & $1.5^{\mathrm{b}}$ & $5.2 \pm 0.8$ & $1.0^{\mathrm{b}}$ \\
\hline 50 & $6.9 \pm 2.3$ & $4.8^{\mathrm{b}}$ & $9.3 \pm 0.8$ & $1.5^{\mathrm{b}}$ \\
\hline
\end{tabular}

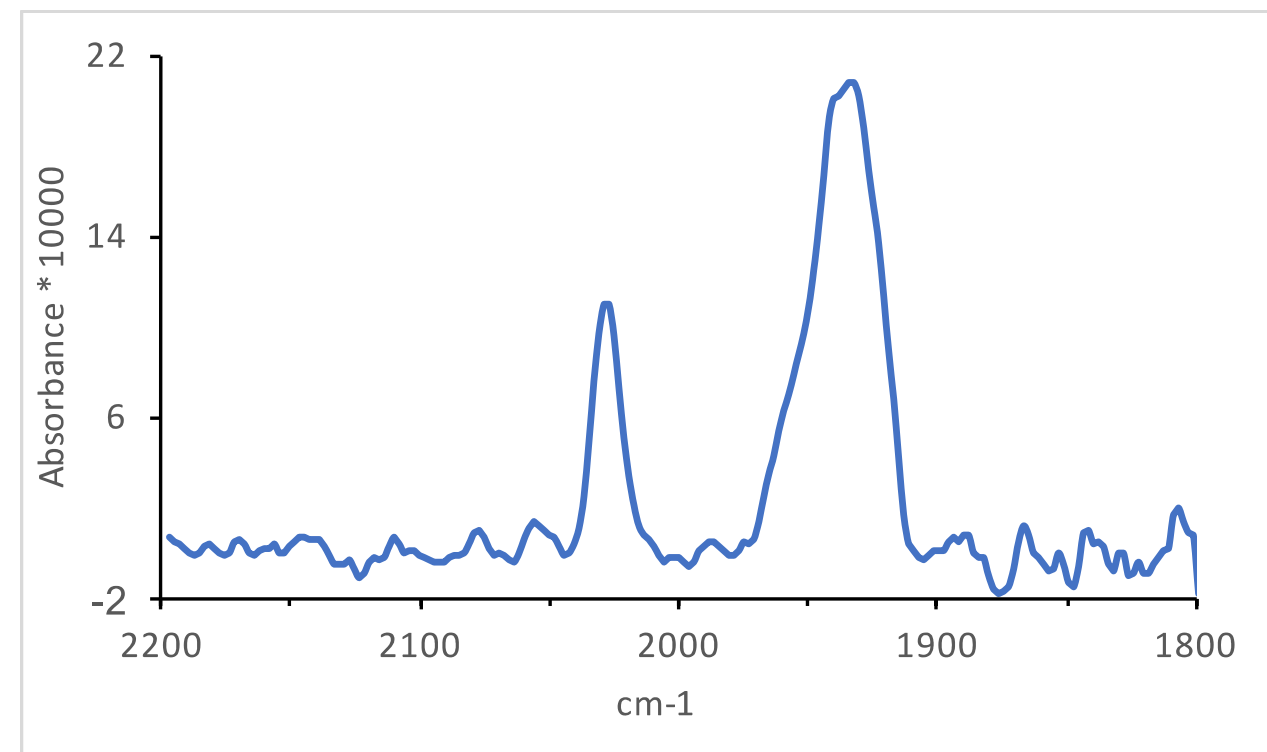

Figure 1. Transmission FT-IR spectrum of a collection of cells (78 000) incubated with 6 $(10 \mu \mathrm{M}) 60 \mathrm{~min}$, on nitrocellulose disk

This series of experiments demonstrates that both complexes accumulate rapidly within cells on a time scale of hours. The quantity of complex increased with incubation concentration and time. Saturation did not seem to be reached even at the highest incubation concentration of $50 \mu \mathrm{M}$. There was no significant difference of behaviour between the two complexes. As a consequence, the higher cytotoxicity of $\mathbf{5}$ with respect to 6 seems to be associated with its own reactivity rather than from a higher accumulation of complex in cells. Taking an estimated volume of $2 \times 10^{-12} \mathrm{~L}$ for a MDAMB-231cell, 33 the intracellular concentration of the complex was found to range from 1.5 to $4.7 \mathrm{mM}$, corresponding to an up to 150 -fold concentration factor in cells. This finding is in good agreement with the high lipophilicity of both complexes. This "sponge- 
like" behaviour of cells was also found for $3^{18}$ and the $\mathrm{CpRe}(\mathrm{CO})_{3}$ derivative of doxorubicin. ${ }^{34}$ As a consequence the amount of complex remaining in the incubation medium and measured by ICP-OES was quite low (see below).

\section{Influence of temperature on internalization of the complexes}

An additional series of experiments was carried out to gain insight into the mechanism of cell uptake of the two complexes. An active uptake mechanism via membrane receptors is energy-dependent and therefore temperature-dependent whereas passive uptake through diffusion across the cell membrane is energyindependent so that the intracellular concentration of complex should not depend on the incubation temperature. Therefore, cells were exposed to 5 or 6 for $60 \mathrm{~min}$ at $4^{\circ} \mathrm{C}$ instead of $37^{\circ} \mathrm{C}$ and the cyrhetrenyl tag was quantified by transmission FT-IR spectroscopy as above (Table 3). Decreased temperature induced a significant decrease of the amount of 5 and $\mathbf{6}$ in cells but both complexes were still detectable after $60 \mathrm{~min}$ incubation at both concentrations tested. It might indicate that these complexes accumulate in cells by both passive diffusion and active transport via receptors. However, since the amounts of 5 and $\mathbf{6}$ increased 1.4-fold and 6-fold when the temperature increased from $4^{\circ} \mathrm{C}$ to $37^{\circ} \mathrm{C}$, active transport mechanisms might be predominant for 6 . Similar behaviour was also reported with a $\operatorname{Re}(\mathrm{CO})_{3}$ derivative of mestranol. ${ }^{35}$

\section{Quantification of metals in cancer cells by ICP-OES}

MDA-MB-231 cells grown in a Petri dish were exposed to 5 at $50 \mu \mathrm{M}$ for $60 \mathrm{~min}$ at $37^{\circ} \mathrm{C}$. At the end of the incubation time, the culture medium was removed and adherent cells were detached, collected by centrifugation, then digested in $\mathrm{HNO}_{3} \cdot{ }^{36}$ Quantification of iron and rhenium in the samples was performed by ICP-OES. The amounts of iron and rhenium found in cells exposed to complex 5 (MDA-MB-231 cells, 60 min incubation, $50 \mu \mathrm{M}$ of 5) were roughly similar (5.8 fmol/cell of iron versus $5.4 \mathrm{fmol} /$ cell of rhenium) indicating that most of the iron quantified by ICP-OES was exogenous and was that provided by the complex and not endogenous iron present in cells. This value is also in the same range as that of the $\mathrm{CpRe}(\mathrm{CO})_{3}$ tag assayed by FT-IR (Table 2). Quantification of rhenium was also performed in the culture medium of cells and was found to equal $6.5 \mu \mathrm{M}$, i.e. $13 \%$ of the initial concentration. This result is consistent with the high 
concentration of $\mathbf{5}$ within cells measured by FT-IR (vide supra). The same experiment was carried out with 6 at $25 \mu \mathrm{M}$ and the amounts of iron and rhenium quantified in cells were equal to 4.8 and $3.5 \mathrm{fmol} /$ cell, respectively. On the whole, the intracellular concentration of exogenous $\mathrm{Re}$ is in the same order of magnitude as that of osmium previously quantified in Jurkat cells (3.9 -4.4 fmol/cell). ${ }^{36}$

\section{Mapping of 6 in MDA-MB-231 cells}

AFM-IR is a technique that uniquely offers the possibility of chemically mapping endogenous and exogenous components in a single cell with a mid-IR source at the resolution of AFM (10-100 nm).37, 38 This resolution is significantly better than that of classic FTIR spectromicroscopy, which is limited by the criterion of light diffraction (Abbe criterion) establishing the resolution limit at a level of $\lambda / 2 .^{6,26}$ We chose to map cells after incubation with complex $\mathbf{6}$, although this is not the most cytotoxic molecule of the series. This is because thorough study of the chemical oxidation of $\mathbf{2}$ (the precursor of 5 ) revealed that the initially obtained tetrahydrofuran substituted quinone methide was cleaved into a multitude of smaller compounds. This behaviour is also very likely to occur for $\mathbf{5}$ (Scheme S2). ${ }^{29}$ Such a mechanism is not possible for compound 6.

To perform the mapping, MDA-MB-231 cells were grown on $\mathrm{CaF}_{2}$ thin slides, then incubated in the presence of $10 \mu \mathrm{M}$ of 6 for $1 \mathrm{~h}$. After washing and PFA fixation, distribution of 6 inside cells was performed with AFM-IR. Cells were first located using their AFM topography (Fig. 2a), then mapped using the AFM-IR setup at several wavenumbers. Images of a single cell, representative of a series of 5, recorded at 1080 $\mathrm{cm}^{-1}$ (characteristic symmetric stretching mode of phosphate of nucleic acids), and 1640 $\mathrm{cm}^{-1}$ (characteristic amide I band of proteins) allowed localization of cell nucleus (Fig. $2 \mathrm{~b}$ and $2 \mathrm{~d}$, red zones). Cellular distribution of compound $\mathbf{6}$ was defined from the image recorded at its characteristic band at $1950 \mathrm{~cm}^{-1}$ (Fig. 2c, red zone). It was co-localized with areas of high density in both amide and phosphate that correspond to the nucleus 18 indicating preferential nuclear localization of 6 . The two characteristic carbonyl stretching bands of 6 in the $2000-1850 \mathrm{~cm}^{-1}$ region were identified in the IR spectra recorded at spots $A$ and $B$ which are located in the zone attributed to the cell nucleus (Fig. 2e, spectra A and B). These spectra are identical to those recorded for precipitate of complex 6 appearing as a red zone at the bottom of the cell (Fig. 2c, spots C and D; Fig. $2 \mathrm{e}$, spectra $\mathrm{C}$ and $\mathrm{D})$. The presence of this precipitate is probably due to the low 
percentage of DMSO used for the experiments $(0.1 \%)$ associated with the high hydrophobicity of the complex.

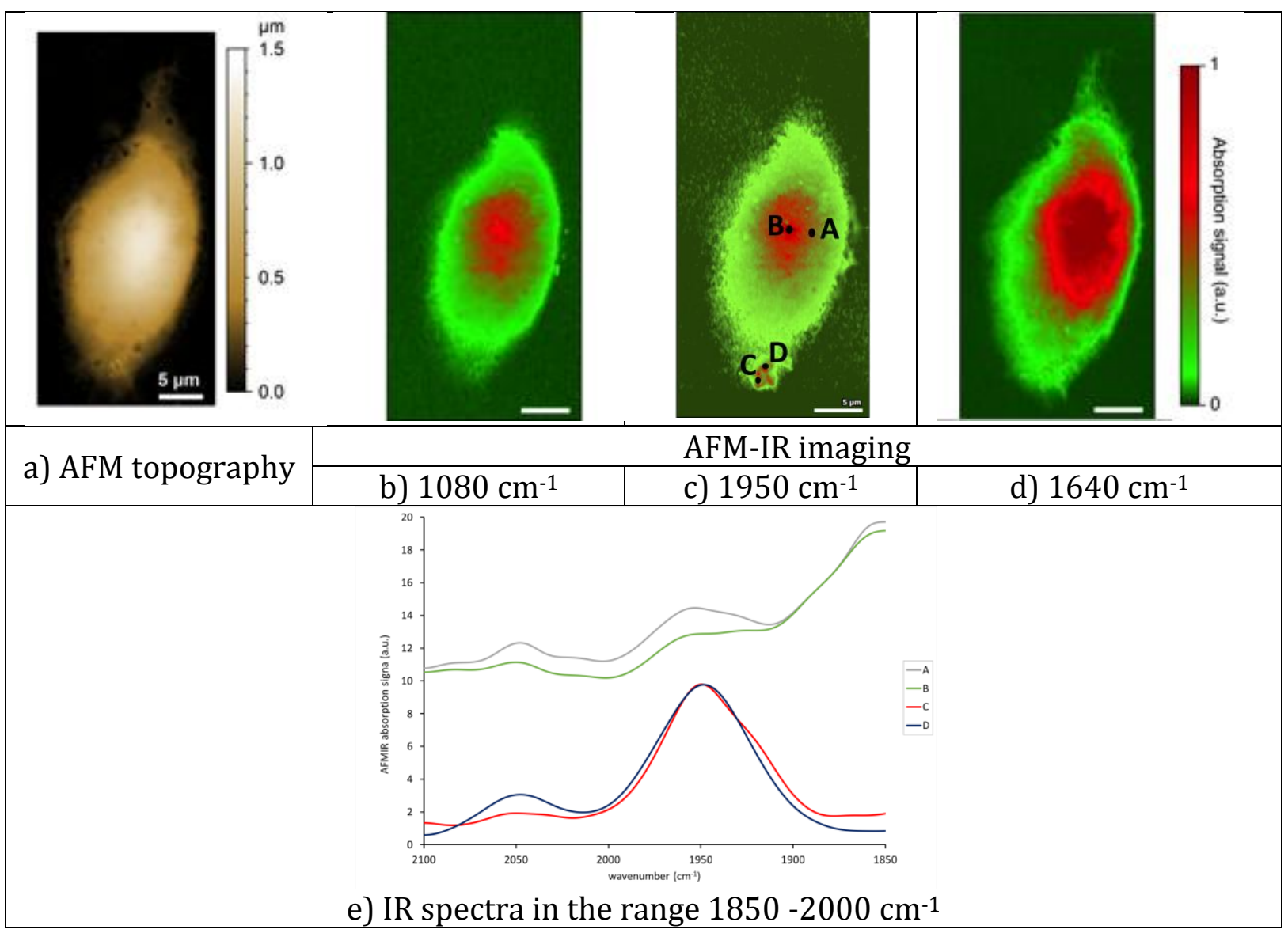

Figure 2 : Top : Images and IR mapping of one MDA-MB-231 cell incubated $1 \mathrm{~h}$ at $37^{\circ} \mathrm{C}$ in the presence of $10 \mu \mathrm{M}$ of 6. a) AFM topography, b-d) AFM-IR images at : b) $1080 \mathrm{~cm}^{-1}$ (phosphate); c) $1950 \mathrm{~cm}^{-1}\left(\operatorname{Re}(\mathrm{CO})_{3}\right)$ of 6); d) $1640 \mathrm{~cm}^{-1}$ (Amide I). Bottom: e) superimposition of AFM-IR spectra, in the 1850-2000 $\mathrm{cm}^{-1}$ range of different spots highly absorbing at $1950 \mathrm{~cm}^{-1}$ (c) A and B : spots in the region attributed to cell nucleus, $\mathrm{C}$ and D spots corresponding to a precipitate of $\mathbf{6}$ present on the cell surface (see AFM topography).

Three other rhenium tricarbonyl complexes 3, 9, 10 (charts 1 and 2) have previously been mapped in MDA-MB-231 cells by SR-FTIR-SM17, 35, 39 and AFM-IR (3 and 10). 17,18 
<smiles></smiles>

9<smiles></smiles>

$\mathrm{OC}_{\mathrm{CO}}^{\mathrm{CO}}$

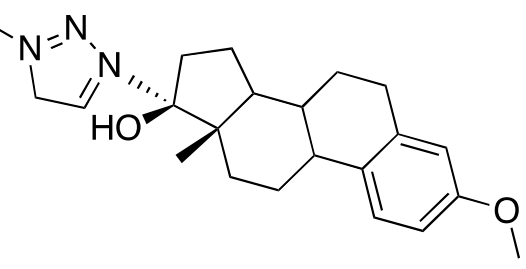

10

Chart 2 : Complexes with a pyta tag $\left[\right.$ pyta $=\operatorname{Re}(\mathrm{CO})_{3} \mathrm{Cl}(\mathrm{L})$ with $\mathrm{L}=4-(2-$ pyrididyl)-1,2,3-triazole] ${ }^{35,39}$

Complex 3 was also observed in the nucleus of MDA-MB-231. In contrast, 9 and 10, the two complexes consisting of a pyta tag linked to long aliphatic chain in 9 or to mestranol in 10, were located in the perinuclear fraction and more precisely in the Golgi apparatus. ${ }^{35,39}$ Recently, Alberto and Gasser reported the synthesis of $\mathrm{CpRe}(\mathrm{CO})_{3} /$ doxorubicin conjugates and found via fluorescence imaging that addition of the cyrhetrene unit diverted the location of doxorubicin from cell nucleus to mitochondria. ${ }^{34}$ In our case, localization of $\mathbf{6}$ in the mitochondria cannot be completely ruled out since AFM-IR mapping does not allow them to be visualized. This is due to the large difference between the volume of mitochondria $\left(1 \mu \mathrm{m}^{3}\right)$ and nucleus $\left(500 \mu \mathrm{m}^{3}\right)$ and the respective quantities of matter inside the two organites. Consequently, the intense thermal expansion of the nucleus detected by the AFM tip precluded observation of the greatly lower thermal expansion induced by mitochondria.

\section{Conclusion}

In conclusion, three new organometallic complexes bearing ferrocenyl and cyrhetrenyl units have been synthesized and fully characterized. They exhibit a high antiproliferative activity on cancer cells (MDA-MB-231; $\mathrm{IC}_{50}$ from 0.32 to $2.5 \mu \mathrm{M}$ ). They are highly lipophilic and their enzymatic oxidation by $\mathrm{HRP} / \mathrm{H}_{2} \mathrm{O}_{2}$ mixture presumably leads to quinone methides that are more stable than those of the parent compounds. Incubation of MDA-MB-231 cells in the presence of $10-50 \mu \mathrm{M}$ of the complexes (5 or $\mathbf{6}$ ) resulted in a high concentration of the complexes inside cells (1.5 to $4.7 \mathrm{mM}$ ) after $1 \mathrm{~h}$. Finally mapping of $\mathbf{6}$, in a single cancer cell, by AFM-IR shows that it is mainly localized in the nucleus.

\section{Acknowledgments}


Y.W. thanks the PGG foundation, the PSL University and Feroscan for financial support and L. H. thanks ENS for PhD fellowship. We thank D. Srivastava for performing transmission IR measurements, P. Pigeon for technical assistance, A. Deniset-Besseau for optimization of AFM-IR protocol.

\section{References}

1. G. Jaouen, A. Vessieres and S. Top, Chem. Soc. Rev., 2015, 44, 8802-8817.

2. Y. Wang, P. Pigeon, S. Top, M. J. McGlinchey and G. Jaouen, Angew. Chem. Int. Ed., 2015, 54, 10230-10233.

3. E. A. Hillard, A. Vessières, L. Thouin, G. Jaouen and C. Amatore, Angew. Chem. Int. Ed., 2006, 45, 285-290.

4. P. Messina, E. Labbé, O. Buriez, E. A. Hillard, A. Vessières, D. Hamels, S. Top, G. Jaouen, Y. M. Frapart, D. Mansuy and C. Amatore, Chem. Eur. J., 2012, 18, 65816587.

5. A. Citta, A. Folda, A. Bindoli, P. Pascal Pigeon, S. Top, A. Vessières, M. Salmain, G. Jaouen and M. P. Rigobello, J. Med. Chem., 2014, 57, 8849-8859.

6. E. Licandro, M. Panigati, M. Salmain and A. Vessieres, in Bioorganometallic Chemistry: Applications in Drug Discovery, Biocatalysis, and Imaging, eds. G. Jaouen and M. Salmain, 2015, pp. 341-391.

7. S. Fery-Forgues and B. Delavaux-Nicot, Journal of Photochemistry and Photobiology a-Chemistry, 2000, 132, 137-159.

8. S. Top, 2018.

9. S. Clede and C. Policar, Chemistry-a European Journal, 2015, 21, 942-958.

10. S. Hostachy, C. Policar and N. Delsuc, Coordination Chemistry Reviews, 2017, 351, 172-188.

11. K. Meister, J. Niesel, U. Schatzschneider, N. Metzler-Nolte, D. A. Schmidt and M. Havenith, Angew. Chem. Int. Ed., 2010, 49, 3310-3312.

12. L. Quaroni, M. Obst, M. Nowak and F. Zobi, Angew. Chem. Int. Ed., 2015, 54, 318322.

13. G. Santoro, T. Zlateva, A. Ruggi, L. Quaroni and F. Zobi, Dalton Trans., 2015, 44, 6999-7008.

14. A. Vessières, J. Organomet. Chem., 2013, 734, 3-16.

15. F. Zobi, L. Quaroni, G. Santoro, T. Zlateva, O. Blacque, B. Sarafimov, M. C. Schaub and A. Y. Bogdanova, J. Med. Chem., 2013, 56, 6719-6731.

16. P. Hildebrandt, Angew. Chem. Int. Ed. , 2010, 49, 4540-4541.

17. S. Clede, F. Lambert, C. Sandt, Z. Gueroui, N. Delsuc, P. Dumas, A. Vessières and C. Policar, Biotechnol. Adv., 2013, 31, 393-395.

18. C. Policar, J. B. Waern, M. A. Plamont, S. Clede, C. Mayet, R. Prazeres, J. M. Ortega, A. Vessieres and A. Dazzi, Angew. Chem. Int. Ed., 2011, 50, 860-864.

19. E. A. Hillard, A. Vessières, S. Top, P. Pigeon, K. Kowalski, M. Huché and G. Jaouen, J. Organomet. Chem., 2007, 692, 1315-1326.

20. A. Nguyen, A. Vessières, E. A. Hillard, S. Top, P. Pigeon and G. Jaouen, Chimia, 2007, 61, 716-724.

21. J. Oyarzo, A. Acuna, H. Klahn, R. Arancibia, C. P. Silva, R. Bosque, C. Lopez, M. FontBardia, C. Calvis and R. Messeguer, Dalton Trans., 2018, 47, 1635-1649.

22. S. Top, A. Vessières, G. Leclercq, J. Quivy, J. Tang, J. Vaissermann, M. Huché and G. Jaouen, Chem. Eur. J., 2003, 9, 5223-5236. 
23. S. Top, J. S. Lehn, P. Morel and G. Jaouen, J. Organomet. Chem., 1999, 583, 63-68.

24. D. J. Minick, J. H. Frenz, M. A. Patrick and D. A. Brent, J. Med. Chem., 1988, 31, 1923-1933.

25. M. G. Pomper, H. VanBrocklin, A. M. Thieme, R. D. Thomas, D. O. Kiesewetter, K. E. Carlson, C. J. Mathias, M. J. Welch and J. A. Katzenellenbogen, J. Med. Chem., 1990, 33, 3143-3155.

26. A. Dazzi and C. B. Prater, Chemical Reviews, 2017, 117, 5146-5173.

27. S. Top, H. El Hafa, A. Vessières, J. Quivy, J. Vaissermann, D. W. Hughes, M. J. McGlinchey, J. P. Mornon, E. Thoreau and G. Jaouen, J. Am. Chem. Soc., 1995, 117, 8372-8380.

28. A. Vessières, S. Top, P. Pigeon, E. A. Hillard, L. Boubeker, D. Spera and G. Jaouen, J. Med. Chem., 2005, 48, 3937-3940.

29. Y. Wang, P. M. Dansette, P. Pigeon, S. Top, M. J. McGlinchey, D. Mansuy and G. Jaouen, Chem. Sci., 2018, 9, 70-78.

30. D. Plazuk, A. Vessières, E. A. Hillard, O. Buriez, E. Labbé, P. Pigeon, M. A. Plamont, C. Amatore, J. Zakrzewski and G. Jaouen, J. Med. Chem., 2009, 52, 4964-4967.

31. A. Gambaro, P. Ganis, F. Manoli, A. Polimeno, S. Santi and A. Venzo, J. Organomet. Chem., 1999, 583, 126-130.

32. A. Simonneau, F. Le Bideau, J. H. Mirebeau, J. Marrot and G. Jaouen, Current Top. Med. Chem., 2017, 17, 2807-2819.

33. http://book.bionumbers.org/how-big-is-a-human-cell).

34. S. Imstepf, V. Pierroz, R. Rubbiani, M. Felber, T. Fox, G. Gasser and R. Alberto, Angew. Chem. Int. Ed., 2016, 55, 2792-2795.

35. S. Clede, F. Lambert, C. Sandt, S. Kascakova, M. Unger, E. Harte, M. A. Plamont, R. Saint-Fort, A. Deniset-Besseau, Z. Gueroui, C. Hirschmugl, S. Lecomte, A. Dazzi, A. Vessieres and C. Policar, The Analyst, 2013, 138, 5627-5638.

36. V. Scalcon, S. Top, H. Z. S. Lee, A. Citta, A. Folda, A. Bindoli, W. K. Leong, M. Salmain, A. Vessieres, G. Jaouen and M. P. Rigobello, J Inorg. Biochem., 2016, 160, 296-304.

37. A. Dazzi, in Thermal Nanosystems and Nanomaterials, ed. S. Volz, 2009, pp. 469503.

38. C. Prater, K. Kjoller, R. Shetty and A. Dazzi, Laser Focus World, 2011, 47, 52-54.

39. S. Clède, F. Lambert, C. Sandt, Z. Gueroui, M. Réfrégiers, M.-A. Plamont, P. Dumas, A. Vessières and C. Policar, Chem. Commun., 2012, 48, 7729-7731. 